\title{
The role of renewable energy sector in reducing unemployment: The Moroccan case
}

\author{
Chama El Moummy ${ }^{1}$, Yahya Salmi $^{2}$, and Hindou Baddih $^{3}$ \\ ${ }^{1}$ Laboratoire des sciences économique et politiques publiques, FSJES Ibn Tofail, Kenitra, Morocco \\ ${ }^{2}$ FSJES Abdelmalek Essaidi, Tangier, Morocco \\ ${ }^{3}$ FSJES université IBN TOFAIL, Kenitra, Morocco
}

\begin{abstract}
The Covid-19 pandemic is putting the world into some very hard times and the labor market is currently experiencing a very significant shock. In Morocco, the unemployment rate has increased since the beginning of the crisis. In the other hand, the world is engaged in a sustainable path and Morocco has started some years ago the deployment of renewable energy sources. After the 2008 crisis, the emergence of the concept of "Green New Deal" has demonstrated the impact of environmental measures and strategies included in many countries recovery plans, on boosting the economy. The objective of this article is to highlight the benefits of green economic recovery policies, on the employment in Morocco, especially for the renewable energy sector. The causality between renewable energy consumption and unemployment will be tested using the VAR model, the Johansen co-integration test, and the Granger causality test, for the period 1990-2017. Our results suggest that there is causality running from renewable energy consumption to unemployment. In fact, renewable energy sector can contribute to reduce the employment rate in Morocco. Investments in the sector can then be made to create jobs, particularly after the Covid-19 pandemic, that caused many jobs losses.
\end{abstract}

\section{Introduction}

The world is experiencing today an unprecedented crisis. The apparition of the new COVID19 virus and its spread in the majority of countries has turned the global system upside down and caused not only a health crisis, but also an economic, political and social crisis. In fact, the affected countries are still waging a fierce fight against the virus and are in the process of taking major measures in order to arrange the situation. However, some consequences are already clear. The measures taken by the majority of states to fight the new Corona Virus have included a general containment of the population which caused many jobs losses. In fact, in Morocco, the national health emergency state has begun on March 20, 2020 and has been going on for several months already. The general containment of the population has led to a total, or a partial shutdown of many businesses, what caused an average of 10.000 of jobs losses per day. Therefore, it is clear that the world, and the country, will need a very important economic recovery program. Even if it is difficult to compare the current economic crisis with the one than the world have faced in 2008, some green economic stimulus that have been taken to promote green growth, can be reproduced in the frame of the Moroccan recovery. In fact, many countries have established green stimulus plans after the crisis, including major green programs and investments. The terms of "Global New Green Deal", "Green New
Deal" and "Green Recovery" then appeared. Those measures were aimed to stimulate the growth of economies after the crisis, particularly through green jobs creation. In fact, several sectors were concerned, in particular the renewable energies sector. In the other hand, Morocco , has been engaged for several years in a path of sustainable development and has increased investments in the renewable energy sector. Endowed with an enormous potential in solar and wind energy, Morocco has started some years ago the deployment of renewable energy sources, and has positioned itself in the first rank of the sector, worldwide. This crisis must represent the opportunity to implement an economic recovery plan, based on green growth by redirecting a part of the economic recovery investments towards green sectors such as renewable energy, which represents today an important possibility of jobs creation.

\section{The concept of "Green growth"}

In order to achieve its growth goals, the world has drawn heavily on its resources and at the same time caused many damages to its environment. In fact, the Club of Rome have denounced the gravity of the world situation and the consequences of the industrialization and the exponential growth model on which the actual system is based. The concept of sustainable development has then emerged. The need to find an economic model that takes into account the environmental and social dimension 
became obvious. However, environmental protection policies are often seen as an obstacle to economic growth. The need to respond to a dual challenge by reconciling economic growth and environmental protection has led to the emergence of the concept of "green growth". In fact, the concept in seen as a practical approach to achieve sustainable development. It means according to the OECD, "The promotion of economic growth and development while ensuring that natural assets continue to provide resources and environmental services, on which our well-being depends ". Green growth suppose then, that it is possible to take advantage of environmental policies in boosting the economy. The simplest definition of green growth would be an economic growth (growth of gross domestic product) while protecting the environment. The UNDP has also clarified the concept of green growth by confirming that protecting the environment generates costs in the short term, but these investments will generate growth in the medium and long term. Green growth suppose then, that economic growth is not only compatible with environmental protection but it could also be the source of a better growth. Green growth therefore relies on investments and innovation in the field of environmental protection, that can lead to the creation of what are called "Green Jobs" and result in the creation of green industries, generating added value.

\section{Literature survey}

The impact on employment is one of the most important socio-economic impacts associated with the deployment of renewable energies. It constitute one of the major concerns of decision-makers who formulate policies in this way. In fact, the literature about the impact of renewable energies on job creation is rich and varied. While some studies analyze the impact of renewable energy on employment using General equilibrium methods or input-output models, others study the causality between renewable energy and unemployment using econometrics tools. In this chapter, we will summarize most important studies concerning the relation between renewables energies and labor market.

Most of the existing studies affirm the positive impact of the deployment of renewable energies on employment, however, the results may vary from one study to another. In fact, results depends on the field of research, the methodology used and data. Garrett Peltier (2017) [1], studied the impact of energy policies and public spending on employment, using an Input-Output Model. The results of the study showed that renewable energy industry generate nearly three times the number of jobs of the fossil industry. The results also suggest that a transfer of a billion dollars invested in fossil fuels to clean energy result in a net increase of about 5,000 jobs. Mu et al. (2018) [2] studied the impact on employment of Chinese renewable energy policies through a multisector general equilibrium model called CHEER and adapted to the country's economy. The results of the study have showed that there is no definite conclusion regarding to the creation of green jobs. In fact, results strongly depend on the type of renewable energie used, the financing mechanisms, and the subsidies dedicated to the sector. The results showed that the direct and indirect effects on employment are positive in all the scenarios studied but are partially offset by the negative induced effects. Bohlmann et al. (2019) [3] examined the economic impacts of a change in the electricity mix in South Africa. Much attention was given to the impact on economic growth and employment. The authors used a recently developed general equilibrium model for South Africa and results showed that the employment level of the country experience only a marginal effect in terms of jobs creation. Similarities in terms of employment impacts were found with $\mathrm{Mu}$ et al. (2018) [2] who also studies the South African case. Khobai, Kolisi et al. (2019) [4] have used the ARDL approach to examine the short and long-term impact of renewable energy consumption on unemployment in South Africa for the period 1990-2014. The results have showed that an increase in renewable energy consumption in South Africa would reduce the unemployment rate in the long run. However, in the short term, the results are not significant. Aliaa Nabil Khodeir (2016) [5] also used the ARDL approach to study the causality between renewable electricity production and unemployment between 1989 and 2013, for the Egyptian case. The results showed that an increase in the production of electricity from renewable sources would reduce unemployment in the long run. The short-term results agree with those of Khobai, Kolisi et al (2019) [4] and do not demonstrate any significant results. The authors explain this result by the fact that renewable energy sources are still in the early stages of deployment and focus more on capital intensity than labor intensity. Kabiru Saidu Musa and Rabiu Maijama (2020) [6] have also studied the causality between renewable energy consumption and unemployment in Nigeria for the period 1991-2015. The authors used the Toda and Yamamoto causality test. The result of longterm causality confirms that there is a bidirectional causality between renewable energy consumption and unemployment as well as between foreign direct investment and renewable energy consumption. The authors recommend the deployment of energy production from renewable sources, and confirms the impact of the sector on reducing the country's unemployment rate. Shuddhasattwa, Ruhul et al. (2018) [7] also studied the relationship between renewable energies consumption and unemployment over a sample of 41 countries and over a period from 1980 to 2014 . The results has shown the positive role of industrialization, service sector, public expenditure and trade openness in reducing unemployment. However, the results have showed that agriculture and renewable energy consumption increase unemployment. Apergisa and Ruhul (2015) [8] also studied the relationship between renewable energy consumption and unemployment for a sample of 80 countries, for the period 1990-2013 using the Granger causality tests. The results of the study showed that the effect of renewable energy consumption on jobs creation depends on the cost 
of renewable energy technologies and energy savings, which appear to vary from one region to another. Bilgili, Ozturk et al. (2017) [9] use a panel dataset from 20 European countries to examine the impacts of energy consumption on youth unemployment over the period 1990-2011; the authors used ordinary least squares estimates Fully Modified by Panel (FMOLS) and Dynamic Ordinary Least Squares (DOLS) as well as Granger causality test. According to the results of the FMOLS and DOLS estimators, energy consumption has a negative impact on the youth unemployment rate. On the other hand, causality tests indicate unidirectional causality running from energy use to youth unemployment rates. Veli, Emel et al. (2020) [10] also studied the impact of new energy technologies on employment and analyzed the causality between the unemployment rate renewable energy consumption for some countries of the Organization for Economic Cooperation and Development ( OECD). The results have showed that there is a strong co-integration relationship between the variables for Australia, Austria, Chile, France, Germany, Japan, Mexico, Portugal, Spain and the United States. The results showed that the use of renewable energy positively affects unemployment rates in Austria, Portugal and Spain, while it negatively affects unemployment rates in Australia, Chile, France, Germany and Japan.

\section{Context}

Our study concerns the Moroccan case. In fact, Morocco is a north African country with many resources, but it is also a country that is facing many challenges such as unemployment. However, the current crisis related to COVID 19 pandemic is worsening the situation. The unemployment rate has significantly increased and went from $9,4 \%$ in 2019 to $27,7 \%$ in 2020 . With a total of 368,000 job losses, including 276,000 in urban areas and 92,000 in rural areas, the overall volume of unemployment reached 1,482,000, according to the latest data from the HCP. In the other hand, Morocco has set several reforms in the favor of environmental protection and is now engaged in a sustainable development strategy. Despite his low rate of greenhouse gas emissions, Morocco has taken preventive measures to protect its natural, social, and economic environment. Actually, one of the current country's priorities is to fight against poverty, unemployment and social disparities, as well as environmental and natural resources protection. Morocco's GHG emissions are principally resulting from the use of fuels and are estimated to $50.5 \mathrm{Mt}$ of $\mathrm{CO} 2$ in 2016 , and should increase rapidly due to the growth of the residential sector and the energy sector. On the other hand, energy needs in Morocco have been increasing for many years due to the economic growth, the household consumption and the electrification of rural areas. However, Morocco is a country that depend heavily on imported energy and do not have any petroleum or coal sources, so the country's trade balance is strongly impacted by the level of energy importation.
This heavy dependence on fossil fuel has convinced the government to reduce its importations and to switch to renewable energy sources, which are abundant. In fact, the country has started some years ago the diversification of the energy mix through the deployment of renewable energy sources. The Moroccan energy strategy aims to increase the share of renewable energies from $42 \%$ of installed capacity in 2020 to $52 \%$ in 2030 . In fact, billion dollars are invested in the Moroccan energy sector between 2016 and 2030 in order to develop a capacity of 10,100 MW integrating 4,560 MW of solar energy, 4,200 MW of wind turbines and 1,330 MW of hydraulic energy. It also aims to reduce greenhouse gas emissions by $32 \%$ by 2030 . In fact, the share of renewable energies in the electricity mix has reached $35 \%$ in 2018 .

\section{Research methods}

This study investigates the relation between renewable energy consumption and unemployment in Morocco for the period 1990-2017 using a VAR model, introduced by Christopher Sims's. The Johansen co-integration test and the Granger causality test are also used to analyze the causality between our variables. Some explicative variables such as public expenditures and gross fixed capital formation are added to our model to set a multivariate framework. In fact, Christopher Sims's research focused on how economic shocks affect the economy. He came with the VAR analysis that only require variables and integrated delays, selection. This model is based on the assumption that the evolution of the economy can be approached by the description of the dynamic behavior of a vector of $\mathrm{N}$ variables. One of the biggest quality of the VAR analysis is that, it avoid having to decide which are the exogenous and endogenous variables of the model. In fact, the model only include endogenous variables. Our econometric model equation is the following :

$$
\mathrm{UN}=\alpha 0+\alpha 1 \mathrm{RE}+\alpha 2 \mathrm{PE}+\alpha 3 \mathbf{G F}+\varepsilon \mathrm{t}
$$

Where :

UN : Unemployment rate

$\alpha 0$ : Model constant;

$\alpha 1, \alpha 2$ : The parameters of the model to be estimated

RE : Renewable energy consumption;

PE : Public expenditure ;

GF : gross fixed capital formation

$\varepsilon t$ : Error term

All data were collected from the World Development Indicators online database.

\section{Empirical analysis and results}

The stationarity test is the first step before estimating our econometric model. It consists of checking the order of integration of the variables used. In fact, Before using the VAR model, it's necessary to investigate the time series proprieties, or non-stationarity properties of the 
variables, In fact, regression with nonstationary variables provides false results. In order to use the VAR model, the variables must be integrated at the same level. In Table 1, we report the results of two different unit root tests, namely the Augmented Dickey-Fuller ( ADF) and PhillipsPerron (PP) used in order to test if the variables are nonstationary and to determine the order of integration. Our results suggest that all our variable are integrated at $\mathrm{I}(1)$ and stationary at the first difference. This leads us to apply a VAR approach in order to investigate the relationship between our variables.

Table 1. Augmented Dickey-Fuller stationary (ADF) and Phillips Perron (PP) stationary test results

\begin{tabular}{|c|c|c|c|c|c|}
\hline & \multicolumn{2}{|c|}{ ADF $(\% 5)$} & \multicolumn{2}{|c|}{$\begin{array}{l}\text { Phillips-Perron (\% } \\
5)\end{array}$} & \multirow[b]{2}{*}{$\begin{array}{c}\text { Nive } \\
\text { au }\end{array}$} \\
\hline $\begin{array}{c}\text { Variab } \\
\text { le }\end{array}$ & $\begin{array}{c}\text { Nivea } \\
\text { u } \\
\text { (Interce } \\
\text { pt) }\end{array}$ & $\begin{array}{l}\text { 1ère. } \\
\text { Différen } \\
\text { ce } \\
\text { (Intercep } \\
\quad \text { t) }\end{array}$ & $\begin{array}{c}\text { Nivea } \\
\text { u } \\
\text { (Interce } \\
\text { pt) }\end{array}$ & $\begin{array}{l}\text { First } \\
\text { differen } \\
\text { ce } \\
\text { (Interce } \\
\quad \text { pt) }\end{array}$ & \\
\hline $\mathrm{RE}$ & $\begin{array}{c}- \\
2.20041 \\
4 \\
- \\
3.58752 \\
7\end{array}$ & $\begin{array}{l}- \\
4.9363 \\
82 \\
- \\
3.5950 \\
26\end{array}$ & $\begin{array}{c}- \\
2.20041 \\
4 \\
- \\
3.58752 \\
7\end{array}$ & $\begin{array}{c}- \\
4.93396 \\
0 \\
- \\
3.59502 \\
6\end{array}$ & I (1) \\
\hline $\mathrm{PE}$ & $\begin{array}{c}- \\
1.68892 \\
8 \\
- \\
3.58752 \\
7 \\
\end{array}$ & $\begin{array}{c}- \\
5.63390 \\
6 \\
- \\
3.60320 \\
2 \\
\end{array}$ & $\begin{array}{c}- \\
1.43632 \\
2 \\
- \\
3.58752 \\
7 \\
\end{array}$ & $\begin{array}{c}- \\
14.9299 \\
1 \\
- \\
3.59502 \\
6 \\
\end{array}$ & I (1) \\
\hline GF & $\begin{array}{c}- \\
2.70551 \\
1 \\
- \\
3.58752 \\
7\end{array}$ & $\begin{array}{c}- \\
4.28482 \\
8 \\
- \\
3.60320 \\
2\end{array}$ & $\begin{array}{c}- \\
2.74265 \\
4 \\
- \\
3.58752 \\
7\end{array}$ & $\begin{array}{c}- \\
5.52957 \\
9 \\
- \\
3.59502 \\
6\end{array}$ & I (1) \\
\hline $\mathrm{UN}$ & $\begin{array}{c}- \\
0.56106 \\
3 \\
- \\
3.64496 \\
3 \\
\end{array}$ & $\begin{array}{c}- \\
5.15219 \\
6 \\
- \\
3.64496 \\
3 \\
\end{array}$ & $\begin{array}{c}- \\
2.94987 \\
8 \\
- \\
3.58752 \\
7 \\
\end{array}$ & $\begin{array}{c}- \\
8.36649 \\
8 \\
- \\
3.59502 \\
6 \\
\end{array}$ & $\mathrm{I}(1)$ \\
\hline
\end{tabular}

Significant at $5 \%$ level

The second step is the the Johansen test witch is the multivariate generalization of the augmented DickeyFuller test. In fact, the generalization is the examination of linear combinations of our variables, as a unit roots. It aims to estimate all co-integrating vectors when there are more than two variables. Our results are reported in table 2 and show that that all of the explanatory and dependent variables are not cointegrated in the long term. So, the type of model to apply is the Vector Auto-Regressive (VAR) model.

We then use the Akaike Information Criterion (AIC), Schwarz Criterion (SC) and Hannan Quinn (HQ) test to determine the appropriate criterion. Our results presented in table 3 suggest that lag 1, is the best choice in our case of study.
Table 2. Johansen test results

Unrestricted Cointegration Rank Test (Trace)

\begin{tabular}{cccc}
\hline \hline $\begin{array}{c}\text { Hypothesized } \\
\text { No. of CE(s) }\end{array}$ & Eigenvalue & $\begin{array}{c}\text { Trace } \\
\text { Statistic }\end{array}$ & $\begin{array}{c}0.05 \\
\text { Critical Value }\end{array}$ \\
\hline \hline None & 0.547790 & 46.43149 & 47.85613 \\
At most 1 & 0.434067 & 25.79766 & 29.79707 \\
At most 2 & 0.276485 & 10.99640 & 15.49471 \\
At most 3 & 0.094533 & 2.581917 & 3.841466 \\
\hline \hline
\end{tabular}

Trace test indicates no cointegration at the 0.05 level $*$ denotes rejection of the hypothesis at the 0.05 level

**MacKinnon-Haug-Michelis (1999) p-values

Unrestricted Cointegration Rank Test (Maximum Eigenvalue)

\begin{tabular}{cccc}
\hline \hline $\begin{array}{c}\text { Hypothesized } \\
\text { No. of CE(s) }\end{array}$ & Eigenvalue & $\begin{array}{c}\text { Max-Eigen } \\
\text { Statistic }\end{array}$ & $\begin{array}{c}0.05 \\
\text { Critical Value }\end{array}$ \\
\hline \hline None & 0.547790 & 20.63383 & 27.58434 \\
At most 1 & 0.434067 & 14.80126 & 21.13162 \\
At most 2 & 0.276485 & 8.414486 & 14.26460 \\
At most 3 & 0.094533 & 2.581917 & 3.841466 \\
\hline \hline
\end{tabular}

Max-eigenvalue test indicates no cointegration at the 0.05 level

* denotes rejection of the hypothesis at the 0.05 level

**MacKinnon-Haug-Michelis (1999) p-values

Table 3. AIC, SC, HQ test results

\begin{tabular}{|c|c|c|c|}
\hline Lag & AIC & SC & HQ \\
\hline 0 & 24.12909 & 24.36698 & 24.20182 \\
\hline 1 & $18.62205^{*}$ & $20.65219^{*}$ & 19.66119 \\
\hline 2 & 19.22483 & 21.23888 & $19.42204^{*}$ \\
\hline
\end{tabular}

Table 4. Granger causality test results

\begin{tabular}{|c|c|c|c|}
\hline Null Hypothesis: & Obs & \begin{tabular}{|l} 
F- \\
Statistic
\end{tabular} & Prob. \\
\hline UN does not Granger Cause RE & 26 & 0.60762 & 0.5539 \\
\hline RE does not Granger Cause UN & & 0.02940 & 0.0311 \\
\hline PE does not Granger Cause RE & 26 & 0.44112 & 0.6491 \\
\hline RE does not Granger Cause PE & & 0.80826 & 0.4590 \\
\hline GF does not Granger Cause UN & 26 & 0.50975 & 0.6079 \\
\hline UN does not Granger Cause GF & & 4.25098 & 0.0282 \\
\hline GF does not Granger Cause PE & 26 & 7.90050 & 0.0028 \\
\hline PE does not Granger Cause GF & & 2.48739 & 0.1073 \\
\hline
\end{tabular}

Knowing the direction of causality is as important as highlighting a link between economic variables. We used Granger causality in this aim. The results are shown in table 4. Our results showed an unidirectional causality between renewable energy consumption and unemployment, between employment and gross fixed capital formation and between gross fixed capital formation and public expenditure. 
Inverse Roots of AR Characteristic Polynomial

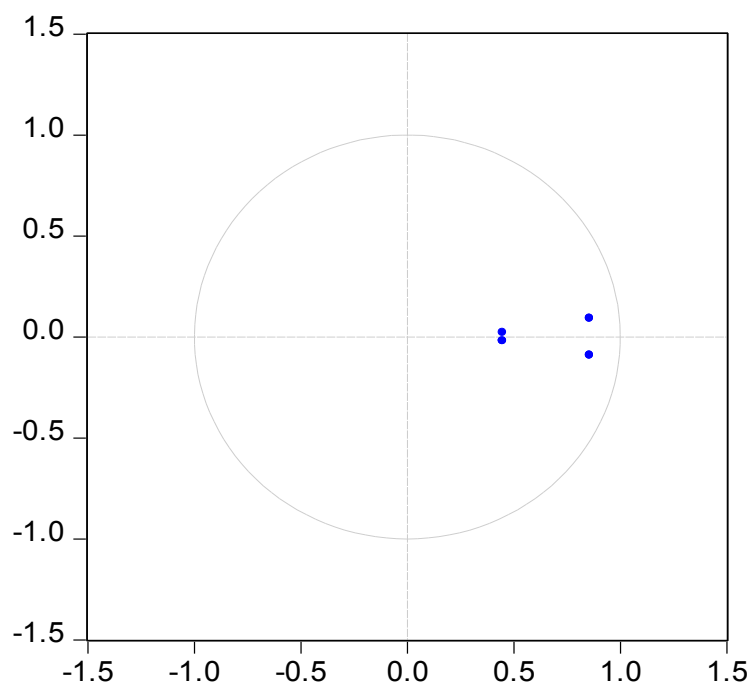

Fig 1. Stationarity test of the VAR model results

Figure 1 represent the results of the stationarity test of the VAR model. The inverse of all the roots are included in the unit circle, according to the stationarity test. The conditions of stationarity are then verified. The VAR model is stationary and is therefore retained.

Table 5. Normality test results

\begin{tabular}{|c|c|c|c|}
\hline Component & Jarque-Bera & df & Prob. \\
\hline 1 & 100.2246 & 2 & 0.0000 \\
\hline 2 & 329.8409 & 2 & 0.0000 \\
\hline 3 & 10.09818 & 2 & 0.0064 \\
\hline Joint & 445.2633 & 8 & 0.7000 \\
\hline
\end{tabular}

Table 5 show the results of the normality test that have demonstrated that the variables are following the normal law. In fact, Jarque-Bera probability $(0.70)$ is greater than $5 \%$. Tthe model is then validated and can be the subject of analysis and economic reflection.

Table (6) is showing our VAR model parameters estimation results. It suggests that an increase of $1 \%$ of renewable energy consumption will lead to a decrease of the unemployment rate by $0,02 \%$. However an increase of $1 \%$ of public expenditure will contribute to the decrease of the unemployment rate by $0,3 \%$. The gross fixed capital formation contribute to reducing the unemployment rate with an average of $0,08 \%$.
Table 6. VAR Model Parameters estimation

\begin{tabular}{|cccccc|}
\hline & & & & \\
& $\mathrm{UN}$ & $\mathrm{RE}$ & $\mathrm{PE}$ & $\mathrm{GF}$ \\
$\mathrm{UN}(-1)$ & 0.512480 & -0.002114 & -0.094342 & -0.166537 \\
& $(0.20868)$ & $(0.18807)$ & $(0.15161)$ & $(0.18814)$ \\
& {$[2.45585]$} & {$[-0.01124]$} & {$[-0.62227]$} & {$[-0.88515]$} \\
& & & & \\
$\mathrm{RE}(-1)$ & -0.02608 & 0.758984 & 0.115537 & 0.054960 \\
& $(0.15054)$ & $(0.13567)$ & $(0.10937)$ & $(0.13573)$ \\
& {$[0.17324]$} & {$[5.59421]$} & {$[1.05639]$} & {$[0.40493]$} \\
$\mathrm{PE}(-1)$ & -0.342663 & 0.023311 & 0.723468 & 0.264253 \\
& $(0.18668)$ & $(0.16824)$ & $(0.13563)$ & $(0.16831)$ \\
& {$[-1.83559]$} & {$[0.13855]$} & {$[5.33429]$} & {$[1.57004]$} \\
& & & & \\
GF(-1) & -0.087225 & -0.153757 & 0.057554 & 0.614418 \\
& $(0.16290)$ & $(0.14682)$ & $(0.11835)$ & $(0.14687)$ \\
& {$[-0.53544]$} & {$[-1.04727]$} & {$[0.48629]$} & {$[4.18328]$} \\
& & & & \\
C & 16.33371 & 7.652191 & 4.578857 & 6.473036 \\
& $(9.15286)$ & $(8.24903)$ & $(6.64977)$ & $(8.25228)$ \\
& {$[1.78455]$} & {$[0.92765]$} & {$[0.68857]$} & {$[0.78439]$} \\
& & & &
\end{tabular}

\section{Conclusion and policy implications}

The contribution of renewable energies to environmental protection and its impact on limiting greenhouses emissions became obvious. However, their impact on macroeconomic and social indicators is still controverted. The concept of green growth stipulate that is it possible to conciliate environmental policies and economic growth. In fact, according to the OECD, "The promotion of economic growth and development while ensuring that natural assets continue to provide resources and environmental services on which our well-being depends" is the definition of the Green growth concept. It suppose then, that it is possible to take advantage of environmental policies in boosting the economy and creating what we call Green jobs. The aim of this article is to examine the relation between renewable energy and unemployment in Morocco. In fact, Morocco has started some years ago, a major deployment of renewable energy sources. However, in the other hand, the country is knowing a very hard times due to the COVID 19 pandemic that has already caused many losses, such as a high increase of unemployment. Using the VAR approach, we studied the relation between renewable energy consumption, public expenditure ,gross fixed capital formation and unemployment rate, over the period 1990-2017, in Morocco. Our empirical results suggest that public expenditure are the most efficient way to decrease unemployment rate. However, renewable energy consumption can also contribute to unemployment rate decreasing, but with a less significant rate. In fact, it is suggested that Moroccan government expenditure should be invested in high employment levels sector, in order to succeed the economic recovery and to boost its economic growth, and improve livings standards in a sustainable way. Same results have been found by Khobai, Kolisi et al 
(2019) [6] who studied the south African case and Aliaa Nabil Khodeir [7] who examined the Egyptian case. For the best of our knowledge, the is no study that have examined the relation between renewable energy and unemployment in Morocco. Our study have proved that renewable energy consumption contribute to decreasing the unemployment rate, but only for $0,02 \%$. This results can be explained by the fact that renewable energy sources are in an early stage of development. However, the sector can have many positive impact such as environmental protection, reduction of imported energy dependency witch can assure to Morocco an energy security, a witch can help the country to reduce its trade balance.

\section{References}

1. Garrett-Peltier, H., "Green versus brown: Comparing the employment impacts of energy efficiency, renewable energy, and fossil fuels using an input-output model" Economic Modelling (2016), http://dx.doi.org/10.1016/j.econmod.2016.11.012

2. Y. Mu, W. Cai, S. Evans, C. Wang, D. Roland-Holst «Employment impacts of renewable energy policies in China: A decomposition analysis based on a CGE modeling framework" Applied Energy, 210, 256267, (2018) https://www.sciencedirect.com /science/article/abs/pii/S0306261917315234?via\%3 Dihub

3. Bohlmann, H.R., J.M. Horridge, R. Inglesi-Lotz, E.L. Roos, et L. Stander. «Regional Employment and Economic Growth Effects of South Africa's Transition to Low-Carbon Energy Supply Mix ». Energy Policy 128 (mai 2019): 830-37. https://doi.org/10.1016/j.enpol.2019.01.065.

4. H. Khobai, N. Kolisi, C. Moyo, Iz. Anyikwa, et S. Dingela «Renewable Energy Consumption and Unemployment in South Africa » International Journal of Energy Economics and Policy, 10 no 2), 170-178, (2020), www.econjournals.com

5. A. Nabil Khodeir, «The Relationship between the Generation of Electricity from Renewable Resources and Unemployment: An Empirical Study on the Egyptian Economy ». Arab Economic and Business Journal 11, no 1 (juin 2016): 16-30. https://doi.org/10.1016/j.aebj.2015.10.003.

6. K. S. Musa, R. Maijama'a "Causal relationship between renewable energy consumption and unemployment in nigeria: evidence from Toda and Yamamoto causality technique", Energy Economics Letters , Vol. 7, No. 1, 46-60, (2020)

7. DOI: 10.18488 /journal.82.2020.71.46.60

8. R. Shuddhasattwa, S.Ruhul et P. M Sgro. «Energy, Unemployment and Trade ». Applied Economics 50, $\begin{array}{lllll}n^{0} & 47 \quad(8 & \text { octobre } & 2018): & 5122-34 .\end{array}$ https://doi.org/10.1080/00036846.2018.1472741.

9. Apergis, et S. Ruhul «Renewable Energy Consumption and Unemployment: Evidence from a Sample of 80 Countries and Nonlinear Estimates ». Applied Economics 47, no 52 (8 novembre 2015):
5614-33.

https://doi.org/10.1080/00036846.2015.1054071.

10. Bilgili, Faik, I. Ozturk, E. Kocak, et U. Bulut. «Energy Consumption-Youth Unemployment Nexus in Europe: Evidence from Panel Cointegration and Panel Causality Analyses » International Journal of Energy Economics and Policy, no 2 (2017): 9.

11. V. Yilanci, E. İSlamoğlu, et S. Yildirimalp. C. Gökçe, «The Relationship between Unemployment Rates and Renewable Energy Consumption: Evidence from Fourier ADL Cointegration Test». Alphanumeric Journal, 30 juin 2020. https://doi.org/10.17093/alphanumeric.669380. 